\title{
AEROMONADS IN SLAUGHTERED CHICKENS: THEIR SPECIES. AND PATHOGENIC FACTORS
}

\author{
Olga CWIKOVÁ, Alena HOVORKOVÁ, O. MRÁZ, Iva STEINHAUSEROVÁ \\ and Z. MATYÁS
}

State Public Health Institute, 61200 Brno

Received October 12, 1992

\begin{abstract}
Cwiková Olga, Alena Hovorková, O. Mráz, Iva Steinhauserová and Z. Matyáš : Aeromonads in Slaughtered Chickens: Their Species and Pathogenic Factors. Acta vet. Brno, 62, 1993: 95-102.

Washings from 155 eviscerated chicken carcasses coming from 16 agricultural co-operatives were examined at 14-day intervals during one year. The isolation attempts yielded 91 aeromonad strains which were further specified, tested for cytotoxicity and examined for pathogenicity for the white mouse.

Aeromonads were found in $13(81 \%)$ agricultural co-operatives, being detected in $58(41.4 \%)$ out of 140 chickens.

Examination of the washings detected $36(39.6 \%)$ A. sobria strains, $21(23.1) \%$ $A$. trota strains, $17(18.7 \%) A$. hydrophila strains, $9(9.9 \%) A$. caviae strains and 8 (8.8) $A$. jandaei strains. On the respective farms 2 to 3 species were generally found in combination.

Of the 91 strains $89(97.8 \%)$ grew in S-phase, $85(93.4 \%)$ haemolysed blood agar and $67(73.6 \%)$ produced cytotoxic effect on tissue culture of MDBK cells. Agreement between all these characteristics was found in $63(69.2 \%)$ strains.

In bioassays the pathogenicity agreed with the results of S-phase growth in 17 $(77.3 \%)$ out of 22 strains, with the results of beta-haemolysis in $16(72.7 \%)$ out of 22 strains and with those of cytotoxicity in $9(69.2 \%)$ out of 13 strains. Agreement between all these three characteristics was found in $9(52.9 \%)$ out of 17 virulent strains.

As pathogenic were classified 3 out of $4 \mathrm{~A}$. caviae strains, 5 out of $8 \mathrm{~A}$. hydrophila strains, 6 out of $8 A$. sobria strains (the remaining two strains grew in R-phase) and all $A$. trota strains examined.
\end{abstract}

Aeromonads, slaughtered chickens, food hygiene

Only motile aeromonads and then particularly $A$. hydrophila, A. sobria and $A$. caviae, associated with gastroenteritis, were described as important from the viewpoint of food hygiene (Janda et al. 1984). Recently, however, it has become apparent that some other species, namely $A$. jandaei (Carnahan et al. 1991b), $A$. veronii (Hickman-Brenner et al. 1987) and possibly also-

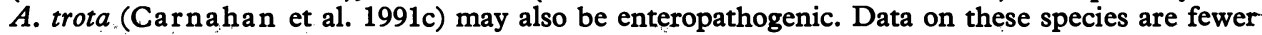
in number and none at all have been recorded in this country.

The only published data on food hygiene-related aeromonads in this country so far have been the findings of $A$. hydrophila in faeces (Paučková and Fukalová 1986) and the information contained in two reports (Kameník 1990, Aldová and Schindler 1991). The present study on aeromonads in slaughtered chickens was therefore carried out to draw attention to this question in our country.

Relevant published data along this line provide information only on the species A. hydrophila; these microorganisms were isolated from poultry purchased from retail dealers ( $\mathrm{Pal}$ umbo et al. 1989) and from refrigerated raw (Nagel et al. 1960) or cooked poultry (Toule and Murphy 1978). The only study approaching our objective is that of Barnhart et al. (1989) who reported the recovery of $A$. hydrophila from broiler carcasses. Our study is concerned in addition with the other aeromonad species and their pathogenic factors. 


\section{Materials and Methods}

Washings from 155 slaughtered chickens coming from 16 agricultural co-operatives were -examined at 14-day intervals during one year. The eviscerated carcasses were put into polyethylene bags containing $100 \mathrm{ml} \mathrm{0.1 \%} \mathrm{peptone} \mathrm{water} \mathrm{and} \mathrm{thoroughly} \mathrm{shaken.} \mathrm{From} \mathrm{each} \mathrm{washing} \mathrm{three}$ dilutions in saline, namely $1: 10,1: 100$ and $1: 1,000$, were prepared from which $0.1 \mathrm{ml}$ aliquots were inoculated into two dishes of blood agar and Endo agar.

After 24 -hour incubation at $37^{\circ} \mathrm{C}$ suspect colonies were transferred to semisolid medium and only facultatively anaerobic motile strains were subjected to further examination. Their identification was carried out with two LACHEMA enterotests supplemented with the following tests: growth in broth without $\mathrm{NaCl}$, nitrate reduction, oxidase reaction and gas production in glucose, all of them conducted at $30^{\circ} \mathrm{C}$. The strains were classified essentially according to the classification scheme of Carnahan et al. (1991a) where only the test for resistance to antibiotics was more or less left out (Table 1).

The characteristics of pathogenicity under study included in addition to beta-haemolysin (Caselitz and Krebs 1962) growth phase in $0.5 \%$ glucose broth (Namdari and Bottone 1988) and the test for cytotoxicity (Chanter et al. 1986). In this test the monolayer of embryonic bovine kidney (MDBK) cells was overlaid with nutrient agar and inoculated with the strain tested. In positive cases the cytotoxic effect was seen after as few as 18 hours of incubation at $37^{\circ} \mathrm{C}$ in the form of variously wide zone of disintegrating monolayer (Fig. 1 and 2).

For evaluation of these tests reportedly related directly to enteropathogenicity (Cumberbatch et al. 1979, Burke et al. 1982) 24 strains were used in bioassays on mice (Nam dari and Bottone 1988). Pairs of mice were inoculated i. p. with doses of $10^{8}$ microbe cells suspended in $0.5 \mathrm{ml}$ saline; where the result was dubious the bioassay was repeated. Each strain that killed at least $50 \%$ of the experimental animals was regarded as pathogenic.

Table 1

Differentiation of the motile aeromonads (CARNAHAN et al. 1991 - modif.)

\begin{tabular}{|c|c|c|c|c|c|c|c|c|}
\hline 莡 & 名 & 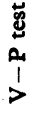 & 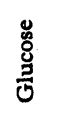 & 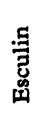 & 㬅 & 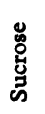 & Species & Importance \\
\hline+ & - & + & AG & - & + & + & A. sorbia & $\begin{array}{l}\text { From stools and blood of hu- } \\
\text { mans }\end{array}$ \\
\hline+ & - & + & $\mathbf{A G}$ & - & + & - & A. jandaei & $\begin{array}{l}\text { From diarrhoeic stools, wounds } \\
\text { and blood of humans }\end{array}$ \\
\hline+ & - & + & $\mathbf{A G}$ & + & - & + & A. hydrophila subsp. hydrophila & $\begin{array}{l}\text { Pathogenic for mammals, fishes, } \\
\text { frogs and snakes }\end{array}$ \\
\hline+ & - & + & $\mathbf{A}$ & + & - & - & $\begin{array}{l}\text { A. hydrophila subsp. anaeroge- } \\
\text { nes }\end{array}$ & \\
\hline+ & - & + & $\mathbf{A}$ & + & + & • & $\begin{array}{l}\text { A. hydrophila subsp. proteoly- } \\
\text { tica }\end{array}$ & \\
\hline+ & - & - & $\mathbf{A}$ & + & - & + & A. caviae & $\begin{array}{l}\text { From diarrhoeic stool of child- } \\
\text { ren }\end{array}$ \\
\hline+ & - & - & AG & + & - & . & A. eucrenophila & Pathogenic only for fishes \\
\hline+ & - & - & AG & - & + & - & A. trota & From stool of humans \\
\hline+ & + & + & AG & + & + & + & A. veronii & $\begin{array}{l}\text { From diarrhoeic stool of chlid- } \\
\text { ren }\end{array}$ \\
\hline- & - & + & $\mathbf{A}$ & - & + & - & A. schubertii & $\begin{array}{l}\text { From abscesses, wounds and } \\
\text { pleural liquid of humans }\end{array}$ \\
\hline
\end{tabular}




\section{Results}

Aeromonads were found in $13(81 \%)$ out of the 16 agricultural co-operatives in a total of $58(41.4 \%)$ out of 140 chickens examined. The isolation attempts yielded 91 strains. From the sinusoid curve (Fig. 3) showing the percentages of eviscerated chickens contaminated with aeromonads during one year it can be seen that the contamination was highest in summer months and lowest in winter months.

The species spectrum of the strains was as follows: $36(39.6 \%) A$. sobria, $21(23.1 \%) A$. trota, $17(18.7 \%) A$. hydrophila, $9(9.9 \%) A$. caviae and $8(8.8 \%)$ $A$. jandaei. On the respective farms (and in $17.4 \%$ of the carcasses) aeromonads of 2 to 3 species were generally found in combination. The number of microbe cells per each species and chicken was $10^{5}$ to $10^{6}$, the average being $5.10^{5}$ cells,

Of the 91 strains $89(97.9 \%)$ grew in S-phase, $85(93.4 \%)$ haemolysed blood agar and $67(73.6 \%)$ produced cytotoxic effect on tissue culture. Agreement between all these characteristics was found in $63(69.2 \%)$ strains (Table 2).

In bioassays on mice the pathogenicity agreed with the results of S-phase growth in $17(77.3 \%)$ out of 22 strains, with the results of beta-haemolysis in $16(72.7 \%)$ out of 22 strains and with those of cytotoxicity in $9(69.2 \%)$ out of 13 strains. Agreement with the pathogenicity with two positive characteristics (growth in S-phase + haemolysis) was recorded in $17(85 \%)$ out of 20 strains and with all three characteristics (including cytotoxicity) in $9(81 \%)$ out of 11 strains.

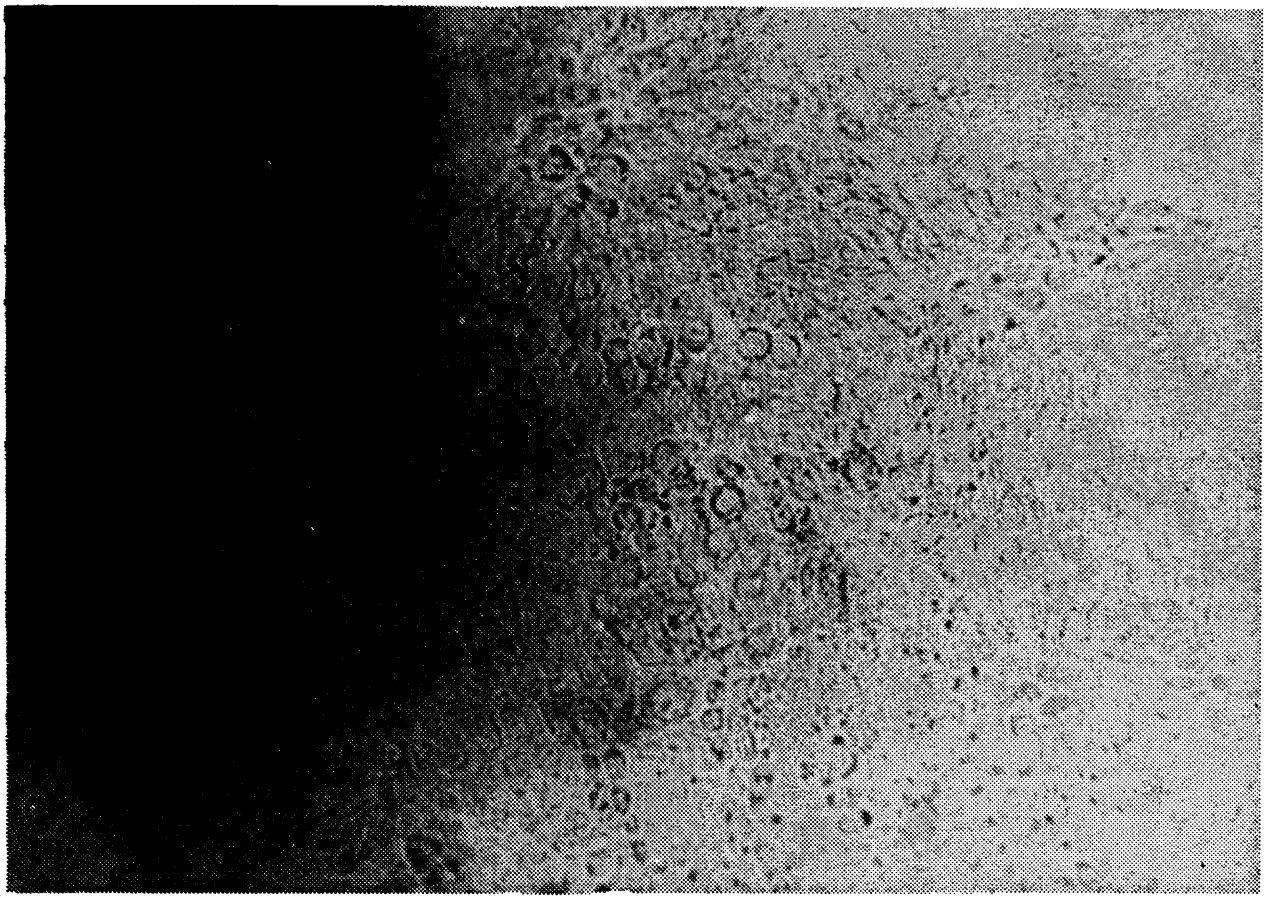

Fig. 1. Negative result of testing for cytotoxicity. Coherent monolayer of MDBK cells. Aeromonas hydrophila, strain No. 7. 


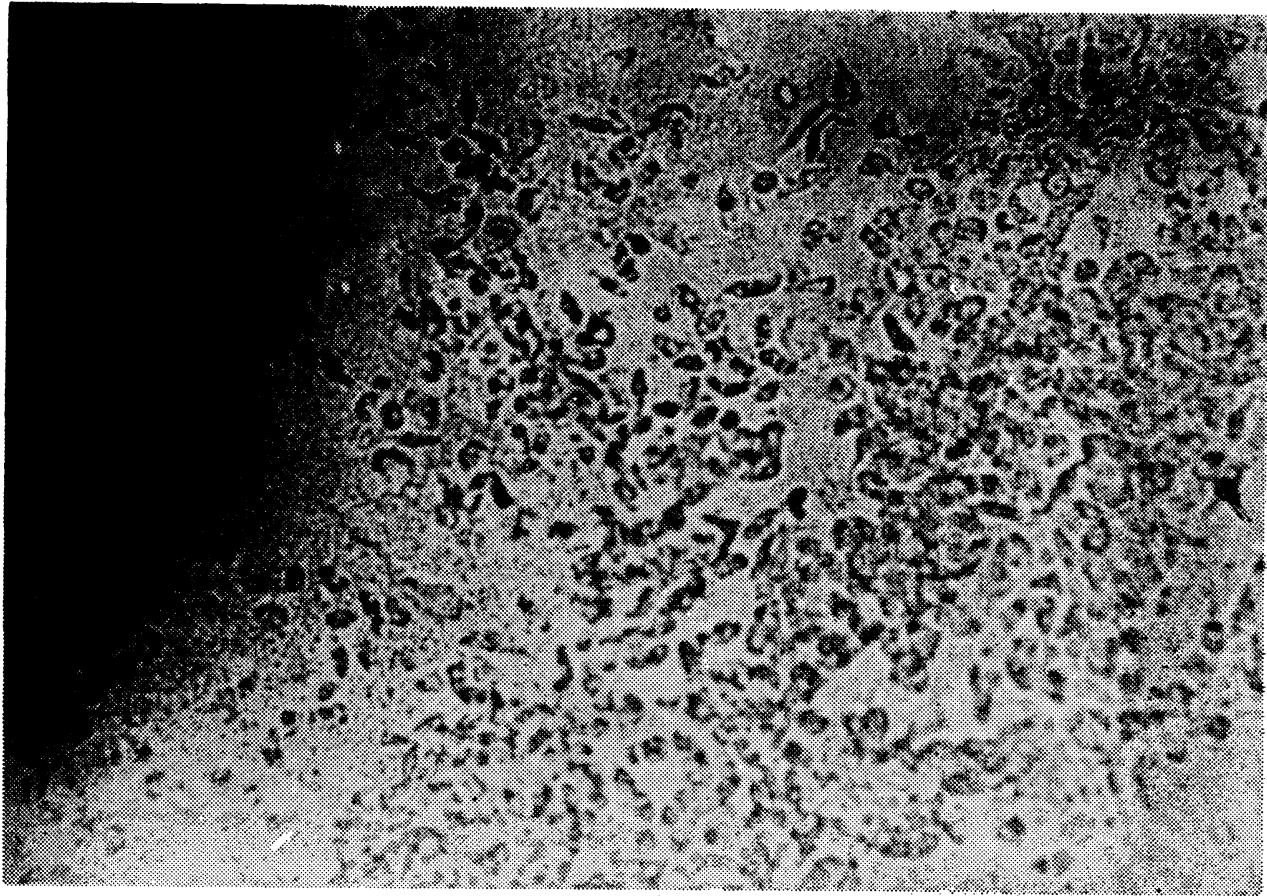

Fig. 2. Positive result of testing for cytotoxicity. Disintegration of the monolayer of MDBK cells. Aeromonas hydrophila, strain No. 10.

As pathogenic were classified 3 out of $4 \mathrm{~A}$. caviae strains, 5 out of $8 \mathrm{~A}$. hydrophila strains, 6 out of $8 \mathrm{~A}$. sobria strains (the remaining two strains grew in R-phase) and all $3 A$. trota strains.

\section{Discussion}

The use of blood and Endo agar for the isolation attempts was dictated by non-existence of a special medium on which all aeromonad species would grow. However, thanks to a very rare occurrence of protei in the diluted washings no difficulties arose and by transferring the suspect colonies from Endo agar possible non-haemolytic strains could also be isolated.

The diagnostic tests were chosen so as to permit differentiation of the strains from related vibria and plesiomonads. As to species characteristics some discordance was recorded more or less only with lysine decarboxylation in the $A$. jandaei - $A$. sobria group, whereas in $A$. hydrophila subspecies where this characteristic is of paramount importance its operation proved satisfactory. A finding of considerable value is the fact that the species $A$. trota and $A$. jandaei were also detected.

No difficulties were encountered in testing for cytotoxicity and the choice of MDBK cells for tissue culture proved adequate. The agreement of this test with the pathogenicity for white mice reached only $69.2 \%$ but was only slightly lower 


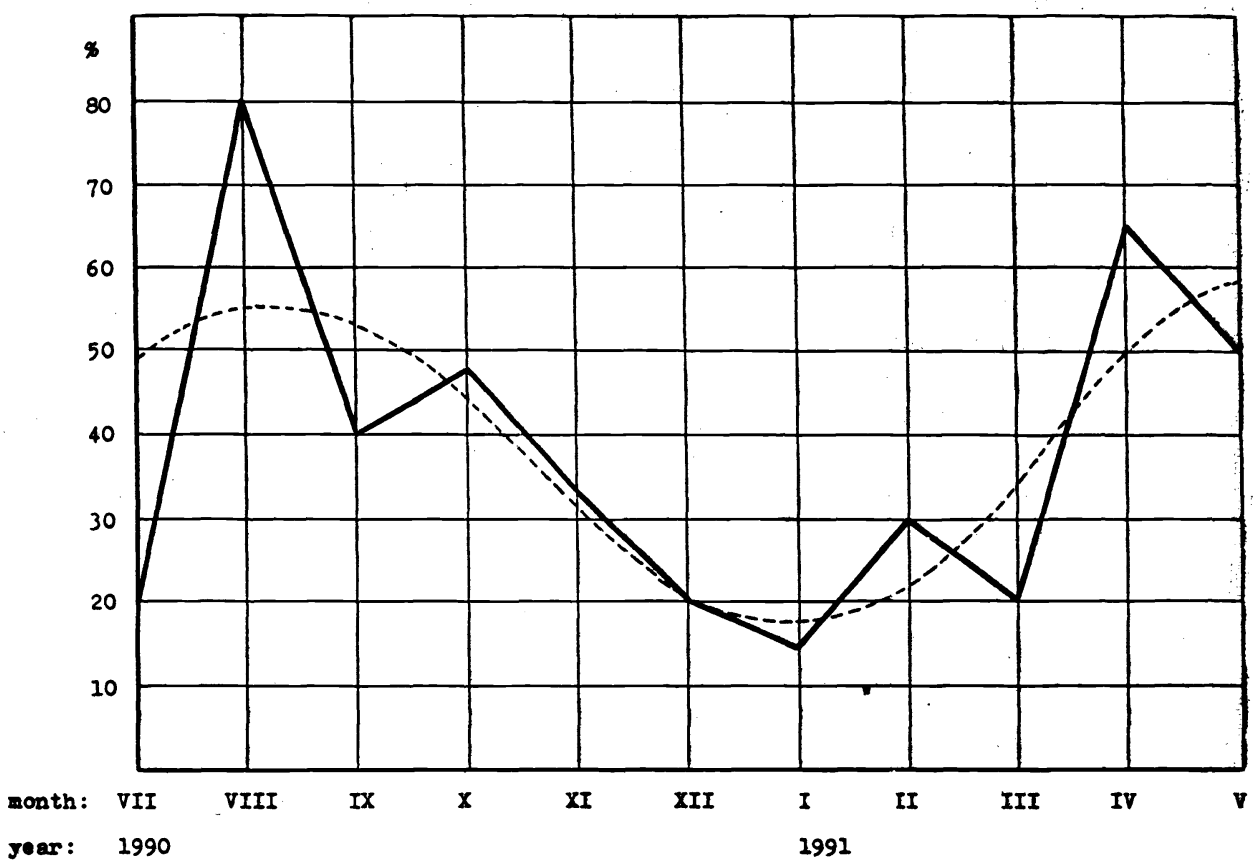

Fig. 3. Percentage of eviscerated chickens contaminated with aeromonads during the year.

Table 2

Some pathogenic factors and results of biological experiments on mice

\begin{tabular}{|c|c|c|c|c|c|c|c|c|c|}
\hline Strain & Phase & $\begin{array}{c}\text { Hemo- } \\
\text { lysis }\end{array}$ & $\begin{array}{c}\text { Cytoto- } \\
\text { xicity }\end{array}$ & $\begin{array}{l}\text { Died/ } \\
\text { /whole }\end{array}$ & Strain & Phase & $\underset{\text { lysis }}{\text { Hemo- }}$ & $\begin{array}{c}\text { Cytoto- } \\
\text { xicity }\end{array}$ & $\begin{array}{l}\text { Died/ } \\
\text { /whole }\end{array}$ \\
\hline \multicolumn{5}{|c|}{ Aeromonas caviae } & \multicolumn{5}{|c|}{ Aeromonas jasdaci } \\
\hline \multirow{2}{*}{$\begin{array}{l}29 \\
30 \\
55 \\
85\end{array}$} & \multirow{2}{*}{$\begin{array}{l}\mathbf{S} \\
\mathbf{S} \\
\mathbf{S} \\
\mathbf{S}\end{array}$} & \multirow{2}{*}{$\begin{array}{l}+ \\
+ \\
+\end{array}$} & \multirow{2}{*}{$\begin{array}{l} \pm \\
-\end{array}$} & \multirow{2}{*}{$\begin{array}{l}3 / 4 \\
2 / 2 \\
0 / 4 \\
2 / 2\end{array}$} & 25 & $\mathbf{S}$ & + & + & $0 / 4$ \\
\hline & & & & & \multicolumn{5}{|c|}{ Aeromonas trota } \\
\hline \multicolumn{5}{|c|}{ Aeromonas hydrophila } & \multirow{2}{*}{$\begin{array}{l}24 \\
37 \\
53\end{array}$} & \multirow{2}{*}{$\begin{array}{l}\mathbf{S} \\
\mathbf{S} \\
\mathbf{S}\end{array}$} & \multirow{2}{*}{$\begin{array}{l}+ \\
\pm \\
-\end{array}$} & \multirow{2}{*}{$\underline{+}$} & \multirow{2}{*}{$\begin{array}{l}2 / 2 \\
2 / 2 \\
2 / 4\end{array}$} \\
\hline \multirow{3}{*}{$\begin{array}{r}1 \\
7 \\
10 \\
18 \\
19 \\
20 \\
66 \\
67\end{array}$} & \multirow{3}{*}{$\begin{array}{l}\mathbf{S} \\
\mathbf{S} \\
\mathbf{S} \\
\mathbf{S} \\
\mathbf{S} \\
\mathbf{S} \\
\mathbf{S} \\
\mathbf{S}\end{array}$} & \multirow{3}{*}{$\begin{array}{l}+ \\
+ \\
+ \\
+ \\
+ \\
+ \\
+ \\
+\end{array}$} & \multirow{3}{*}{$\begin{array}{l}- \\
+ \\
+ \\
+ \\
+ \\
+ \\
+\end{array}$} & \multirow{3}{*}{$\begin{array}{l}2 / 2 \\
2 / 2 \\
2 / 4 \\
0 / 4 \\
3 / 4 \\
1 / 4 \\
3 / 4 \\
2 / 4\end{array}$} & & & & & \\
\hline & & & & & \multicolumn{5}{|c|}{ Aeromonas sobria: } \\
\hline & & & & & $\begin{array}{r}2 \\
12 \\
17 \\
28 \\
31 \\
41 \\
51 \\
81\end{array}$ & $\begin{array}{l}R \\
S \\
S \\
R \\
S \\
S \\
S \\
S\end{array}$ & $\begin{array}{l}+ \\
+ \\
+ \\
+ \\
+ \\
+ \\
+ \\
+\end{array}$ & $\begin{array}{l}+ \\
+ \\
+ \\
+ \\
+ \\
+ \\
+\end{array}$ & $\begin{array}{l}0 / 4 \\
2 / 4 \\
3 / 4 \\
0 / 4 \\
3 / 4 \\
2 / 2 \\
2 / 4 \\
2 / 2 \\
\end{array}$ \\
\hline
\end{tabular}


than the results recorded for beta-haemolysis (72.7\%) and S-phase growtin (77.3\%). The question thus arises as to the conformity between these factors of virulence and enteropathogenicity of the strains as has been repeatedly claimed in the relevant literature (Cumberbatch et al., Burke et al., Namdari and Bottone). Such conformity was not confirmed by our results, is not apparent from those reported by Palumbo et al. (1985) and was rejected by Morgan et al. (1985).

For evaluation of possible human health risks posed by an aeromonad strain in food it is therefore necessary either to assess its enterotoxin production (a process highly demanding as yet) or to identify its species. $A$. hydrophila, $A$. sobria and A. caviae in which this toxin was demonstrated (Wats on et al. 1985) have been acknowledged as potential enteropathogens. The aetiological role of other aeromonad species in diarrhoeal disease has yet to be determined.

\section{Aeromonády u jatečných kuřat, jejich druhové zastoupení a patogenní faktory}

Během jednoho roku byly ve 14denních intervalech vyšetřeny oplachy $z$ eviscerovaných trupů 155 kuřat, pocházejících ze 16 zemědělských družstev. Bylo izolováno celkem 91 kmenư aeromonád, jež byly dále specifikovány, zkoušeny na cytotoxicitu a v biologických pokusech také na patogenitu pro bílou myš.

Aeromonády byly nalezeny ve $13(81 \%)$ zemědělských družstvech, a to u 58 $(41,4 \%)$ ze 140 kuřat.

V oplaších se zjistilo $36(39,6 \%)$ kmenů $A$. sobria, 21 (23,1 \%) kmenů $A$. trota, $17(18,7 \%)$ kmenů $A$. hydrophila, $9(9,9 \%)$ kmenů $A$. caviae a $8(8,8 \%)$ kmenů $A$. jandaei. $\mathrm{V}$ jednotlivých chovech se vyskytovaly vesměs $\mathrm{v}$ kombinacích $2-3$ druhů.

Z celkového počtu kmenů rostlo $89(97,8$ \%) v S-fázi, 85 (93,4 \%) hemolyzovalo krevní agar a $67(73,6 \%)$ dalo cytotoxický efekt na tkáňové kultuře buněk MDBK. Konformita ve všech těchto znacích souçasně, byla zjištěna u $63(69,2 \%)$ kmenů.

$\mathrm{V}$ biologických pokusech prokázalo souhlas $\mathrm{s}$ patogenitou u S-fáze růstu 17 $(77,3 \%)$ ze 22 kmenů, u beta-hemolýzy $16(72,7 \%)$ ze 22 kmenů a u cytotoxicity $9(69,2 \%)$ ze 13 kmenů. Konformita ve všech třech znacích současně, byla zjištěna u $9(52,9 \%)$ ze 17 virulentních kmenů.

Podle jednotlivých druhů se projevily jako patogenní 3 ze 4 kmenů $A$. caviae, $5 \mathrm{z} 8$ kmenů $A$. hydrophila, 6 z 8 kmenů $A$. sobria (zbylé dva rostly v R-fázi) a všechny 3 použité kmeny $A$. trota.

\section{Аэромонады у үбойных цыплят, их пдедставление по видам и патогенные факторы}

В течение одного года в двухнедельных интервалах проводили исследования промывной жидкости 155 выпотрошенных цыплят из 16 сельскохозяйственных кооперативов. Изолировали в итоге 91 штамм аэромонад, которые впоследствии уточныли, проверяли цитотоксичность и в биологических экспериментах также патогенность для белой мыши.

Аэромонады были установлены в 13 (81\%) кооперативах, а именно у $58(41,4 \%)$ из 140 цыплят. 
В промывной жидкости было установлено 36 (39,6 \%) штаммов A. sobria, $21(23,1 \%)$ штамм A. trota, $17(18,7 \%)$ штаммов A hydrophila, $9(9,9 \%)$ штаммов А. caviae и $8(8,8 \%)$ штаммов A. jandaei. На отдельных птицеводствах они большей частью встречались в комбинации $2-3$ видов.

Из общего числа штаммов $89(97,8 \%)$ расли в S-фазе $85(93,4 \%)$ гемолизировали кровяной агар и $67(73,6 \%)$ отличались цитотоксическим эффектом на тканевой культуре клеток MDBK. Конформность всех упомянутых признаков одновременно была установлена у 63 $(69,2 \%)$ штаммов.

В биологических экспериментах было выявлено согласие с патогенностью у S-фазы роста $17(77,3 \%)$ из 22 штаммов, у бета-гемолиза - $16(72,7 \%)$ из 22 штаммов и у цитотоксичности - $9(69,2 \%)$ из 13 штаммов. Конформность у всех трех признаков одновременно была установлена у $9(52,9 \%)$ из 17 вирулентных штаммов.

По отдельным видам патогенными оказались 3 из 4 штаммов $A$. caviae, 5 из 8 штаммов A. hydrophila, 6 из 8 штаммов A. sobria (оставшиеся два штамма расли в R-фазе) и все три испопьзуемые штамма A. trota.

\section{References}

AGGER, W. A.-McCORMICK, J. D.-GURWITH, M. J.: Clinical and microbiological features of Aeromonas hydrophila - associated diarrheia. J. Clin. Microbiol., 21, 1985: 909-913 ALDOVA, E. - SCHINDLER, J.: Rod Aeromonas (Souborný referát). Čs. Epidem., 40, 1991: $177-190$

BARNHART, H. M.-PANCORBO, O. C.-DREESEN, D. W.-SHOTTS, E. B.: Recovery of Aeromonas hydrophila from carcasses and processing water in a broiler processing operation J. Food Protect., 52, 1989: 646-649

BURKE, V.-ROBINSON, J.-ATKINSON, H. M.-GRACEY, M.: Biochemical characteristics of enterotoxigenic Aeromonas spp. J. Clin. Microbiol., 15, 1982: 48-52

CAHILL, M. M.: Virulence factors in motile Aeromonas species (A review). J. of Applied Bact., 69, 1990: 1-16

CARNAHAN, A. M.-BEHRAM, S.-JOSEPH, S. W.: Aerokey II: A flexible key for identifying clinical Aeromonas species. J. Clin. Microbiol., 29, 1991a: 2.843-2.849

CARNAHAN, A.-FANNING, G. R.-JOSEPH, S. W.: Aeromonas jandaei (formerly genospecies DNA group $9 \mathrm{~A}$. sorbia), a new sucrose-negative species isolated from clinical specimens. J. Clin. Microbiol., 29, 1991b: 560-564

CARNAHAN, A. M. - CHAKRABORTY, T.-FANNING, G. R. - VERMA, D. -ALI, A.JANDA, J. M.-JOSEPH S. W.: Aeromonas trota sp. n., an ampicillin-susceptible species isolated from clinical specimens. J. Clin. Microbiol., 29, 1990c: $1.206-1.210$

CASELITZ, F. H.-KREBS, D.: Über die Tierpathogenität von Aeromonas-Stämmen. Zbl. Bakt. I. Orig., 187, 1962: 56

CHANTER, N.-RUTTER, J. M. - LUTHER, P. D.: Rapid detection of toxigenic Pasteurella multocida by an agar overlay method. Vet. Record, 119, 1986: 629-630

CUMBERBATCH, N.-GURWITH, M. J.-LANGSTON, C.-SACK, R. B.-BRUNTON, J. L.: Cytotoxic enterotoxin produced by Aeromonas hydrophila: Relationship of toxigenic isolates to diarrhoeal disease. Infect. Immun., 23, 1979: 829-837

HICKMAN-BRENNER, F. W. - MCDONALD, K. L. - STEIGERWALT, G. R. - FANNING, G. R. - BRENNER, D. J.-FARMER, J. J.: Aeromonas veronii, a new ornithine decarboxylase positive species that may cause diarrhea. J. Clin. Microbiol., 25, 1987: 900-906

JANDA, J. M. - REITANO, M. - BOTTONE, E. J.: Biotyping of Aeromonas isolates as a correlate to delineating a species-associated disease spectrum. J. Clin. Microbiol., 19, 1984: 44-47

KAMENÍK, J.: Rod Aeromonas a jeho význam v hygieně potravin. Veterinářství, 40, 1990: 560

NAGEL, C. W.-SIMPSON, K. L.-VAUGHN, R. H. -STEWART, G. F.: Microorganisms associated with spoilage of refrigerated poultry. Food Technol., 21, 1960: 21-23 
MORGAN, D. R.-JOHNSON, P. C. - du PONT, H. L.-SATTERWHITE, J. K. - WOOD, L. V.: Lack of correlation between known virulence properties of Aeromonas hydrophila and enteropathogenicity for humans. Infect. and Immunity, 50, 1985: 62-65

NAMDARI, H.-BOTTONE, E. J.: Correlation of the suicide phenomenon in Aeromonas species with virulence and enteropathogenicity. J. Clin. Microbiol., 26, 1988: 2.615-2.619

NAMDARI, H. - BOTTONE, E. J.: Cytotoxin and enterotoxin production as factors delineating enteropathogenicity of Aeromonas caviae. J. Clin. Microbiol., 28, 1990: 1.796-1.798

PALUMBO, S. A.-DONNA, R.-MORGAN-BUCHANAN, R. L.: Influence of temperature, $\mathrm{NaCl}$, and $\mathrm{pH}$ on the growth of Aeromonas hydrophila. J. Food Science, 50, 1985: 1.417-1.421

PALUMBO, S. A.-MARIANNE, M.-BENCIVENGO-CORRAL, F.-WILLIAMS, A. C. -BUCHANAN, R. L.: Characterization of the Aeromonas hydrophila group isolated from retail foods of animal origin. J. Clin. Microbiol., 27, 1989: 854-859

PAUČKOVÁ, V.-FUKALOVÁ, A.: Occurence of Aeromonas hydrophila and Aeromonas shigelloides in faeces. Zbl. Bakt., A 206, 1968: 212-216

POTOMSKI, J, -BURKE, V.--WATSON, I.-GRACEY, M.: Purification of cytotoxic enterotoxin of Aeromonas sobria by use of monoclonal antibodies. J. Med. Microbiol., 23, 1987: $171-177$

TOULE, G.-MURPHY, O.: A study of bacteria contaminating refrigerated cooked chicken, their spoilage potencial, and possible origin, J. Hyg., 81, 1978: 161-169

WATSON, I. M.-ROBINSON, J. O.-BURKE, V.-GRACEY, V.: Invasiveness of Aeromonas spp. in relation to biotype, virulence factors and clinical features. J. Clin. Microbiol., 22, 1985: 48-51 